\title{
Editorial
}

\section{Las enfermeras visitadoras y la salud pública al concluir la fase armada de la Revolución Mexicana}

Al culminar la fase armada de la Revolución Mexicana (1910-1920), fomentar la salud física, mental y moral de la población, devinieron en temáticas esenciales de gobierno, así como en asuntos ampliamente comentados por diversos médicos, higienistas, políticos, educadores y profesores de instrucción pública. Es decir, después de una década marcada por la violencia, la inseguridad, el hambre y la enfermedad, en la que se estima que el país perdió a más del cinco por ciento de la población por causas relacionadas directa o indirectamente con la contienda bélica, se consideró como esencial la higienización colectiva de la sociedad.

Un promotor clave de esa empresa de saneamiento integral fueron las enfermeras visitadoras, quienes para el caso particular de la ciudad de México, se ocuparon de recorrer sus barrios más pobres y densamente poblados para supervisar y dar seguimiento constante a la mujer embarazada, a la nueva madre y a la niñez. De acuerdo con las autoridades de salud, las labores de las visitadoras eran fundamentales para elevar la esperanza de vida y para prevenir la muerte de los niños entre los 0 y los 2 años de edad. Por tanto, se puede afirmar que las labores de las visitadoras fueron fundamentales: a ellas se les confi- rió la responsabilidad de acudir a los hogares y de llevar en forma directa, clara y precisa las enseñanzas de la medicina preventiva.

La enfermera visitadora, a diferencia de la enfermera titulada que trabajaba en una clínica u hospital, tenía como entorno primordial de sus labores el ámbito doméstico, y entre sus responsabilidades destacaban las que siguen: supervisar la higiene y salubridad de las habitaciones; vigilar que la mujer diera cabal seguimiento a las indicaciones requeridas durante

\section{la presencia}

\section{y actuación}

\section{de las enfermeras}

visitadoras no se puede

separar del enorme

interés que a nivel

internacional tuvo

la promoción

de la salud

\section{materno-infantil entre}

1880 y 1930 el embarazo y post-parto; vigilar que los niños desde el nacimiento hasta los dos años de edad recibieran una adecuada atención y alimentación para garantizar su sano crecimiento, y aconsejar a las mujeres acerca de los procedimientos, hábitos y costumbres necesarios para devenir en una madre capaz, responsable y científicamente preparada. Esas labores fueron calificadas como absolutamente indispensables en un país como México, donde el analfabetismo, la insalubridad, la desconfianza y el rechazo hacia los médicos, la medicina y sus instituciones, ponían en entredicho el éxito de cualquier programa de salud pública.

Es importante destacar que la preponderancia que adquirió la presencia y actuación de las enfermeras visitadoras no se puede separar del enorme interés que a nivel internacional tuvo la promoción de la salud materno-infantil entre 1880 y 1930 . Durante esos años "salvar a la niñez" fue un catalizador importante de muy diversos programas médicos, sociales y asistenciales. Así, en la figura de la enfermera visitadora se unió el conocimiento científico especializado a la tradición caritativa y educadora de las damas visitadoras, presentes con relativa abundancia en diversos países europeos y del continente americano durante el transcurso del siglo 
XIX y las primeras décadas del siglo pasado.

La formación de las primeras enfermeras visitadoras en la ciudad de México inició en la Escuela de Salubridad en 1925 en congruencia con el anhelo de dotar al país de un verdadero "ejército sanitario". Un informe de la Escuela de Salubridad estableció que durante el año escolar comprendido entre julio de 1926 y junio de 1927, el número de mujeres que obtuvo el diploma de enfermera visitadora fue de 31. Cifra que se repitió con pequeñas variaciones en 1929 y 1930. Sin embargo, otro informe de 1927 asentó que el número de mujeres que asistió a alguno de los cursos fue de 2,095. Lo anterior apunta hacia la extraordinaria recepción que tuvo la apertura de una novedosa forma para ingresar al mundo del trabajo asalariado, un trabajo que además denotaba un enorme compromiso social en aras de la resolución de los problemas más básicos de salud de la población.

Durante el transcurso de la segunda mitad de la década de 1920, los Centros de Higiene Infantil (CHI) ubicados en las colonias más pobres y densamente pobladas de la capital fueron los ámbitos desde dónde las enfermeras visitadoras realizaron sus primeros trabajos. Los $\mathrm{CHI}$ requerían atraer la atención de la población femenina de la ciudad de México, y para ello organizaban rifas y sorteos mensuales en los que se premiaba a las señoras que concurrían puntualmente a sus consultas; proyectaban películas sobre temas higiénicos, como por ejemplo las tituladas "Cuidados PreNatales" o "Cuidados a los niños", y organizaban concursos y festividades, como los llamados Concursos de Niños Sanos. Y como ya se mencionó, fueron precisamente los $\mathrm{CHI}$ los que organizaron las primeras labores de las visitadoras. Por lo general, se le entregaban listados de las visitas que requerían realizar a los domicilios de las pacientes con instrucciones precisas, especificándose si la visita era de conquista, de reconquista o de seguimiento. Al llegar a los domicilios, las visitadoras levantaban censos sanitarios; recababan información sobre la situación marital de las mujeres y buscaban la cooperación de la población para vacunar a los infantes contra la viruela. Aunado a lo anterior, las visitadoras tenían en sus manos la obligación de llevar al hogar, en forma prác-

\section{Las enfermeras}

\section{visitadoras}

se sumaron

a la tarea de

promover profundas

transformaciones

en los hábitos

\section{y costumbres}

\section{de los mexicanos}

tica sencilla y objetiva, los consejos y los cuidados proporcionados por los Centros de Higiene, así como dirigir a la futura madre y al niño al divulgar los preceptos de higiene general. En promedio las visitadoras realizaban cinco visitas por día, y en cada una requerían tener presente que en sus labores debía destacar la paciencia, la puntualidad, la limpieza, la amabilidad y el buen humor.
Una tarea no menos importante de las visitadoras fue organizar los llamados "clubs" o asociaciones de "pequeñas madres" en diversas escuelas públicas de la capital. En éstos, daban a conocer a las niñas de entre los 12 y 14 años las atenciones y cuidados que requerían recibir los bebés, las reglas de higiene que necesitaban seguir al pie de la letra en la casa y en la escuela, y los peligros que representaban para la salud individual y colectiva los gérmenes, microbios y bacterias. Con ello, las autoridades de salud deseaban sembrar en las futuras madres los principios básicos de la medicina preventiva y evitar -que por ignorancia o desconocimientopropagaran enfermedades infectocontagiosas.

En suma, las acciones desempeñadas por las enfermeras visitadoras fueron indispensables para fomentar la salud pública, la medicina preventiva y la salud materno-infantil a partir de la segunda mitad de la década de 1920. Para los gobiernos emanados de la Revolución, la reconstrucción nacional se sustentó en gran medida en una política educativa que tenía por objetivo crear a un nuevo ciudadano, cuyos rasgos principales requerían ser la sobriedad, la disciplina, el trabajo y la higiene. Así, la escuela y sus maestros, los médicos e higienistas, y las enfermeras visitadoras se sumaron a la tarea de promover profundas transformaciones en los hábitos y costumbres de los mexicanos. Lo anterior tuvo lugar durante un momento cuando comenzó a ser preponderante a nivel internacional la protección de la salud de la niñez y de la mujer embarazada, temáticas que para las autoridades de salud del país también fueron primera importancia.

Dra. Claudia Agostoni Instituto de Investigaciones Históricas, UNAM 